\title{
Application of different techniques to detect Toxoplasma gondii in slaughtered sheep for human consumption
}

\author{
Utilização de diferentes técnicas para detecção de Toxoplasma gondii em ovinos \\ abatidos para consumo humano
}

Annelise Castanha Barreto Tenório Nunes ${ }^{1}$; Edna Maria Vieira da Silva²; José Aelson de Oliveira²;

Elise Myuki Yamasaki ${ }^{3}$; Pomy de Cássia Peixoto Kim³; Jonatas Campos de Almeida ${ }^{3}$; Kleber Barros Nunes;

Rinaldo Aparecido Mota ${ }^{3 *}$

\author{
${ }^{1}$ Laboratório de Histologia e Patologia Veterinária, Departamento de Medicina Veterinária, Universidade Federal de Alagoas - UFAL, \\ Viçosa, AL, Brasil \\ ${ }^{2}$ Veterinário Autônomo, Maceió, AL, Brasil \\ ${ }^{3}$ Laboratório de Doenças Infecto-contagiosas dos Animais Domésticos, Departamento de Medicina Veterinária, Universidade Federal \\ Rural de Pernambuco - UFRPE, Recife, PE, Brasil \\ ${ }^{4}$ Centro de Controle de Zoonoses - CCZ, Maceió, AL, Brasil
}

Received July 21, 2015

Accepted August 31, 2015

\begin{abstract}
The aim of this study was to investigate occurrence of Toxoplasma gondii in sheep slaughtered in the state of Alagoas, Brazil, by means of different diagnosis techniques. Serum samples and tissues from 100 slaughtered sheep were used. To detect antibodies, the indirect immunofluorescence antibody test (IFAT) was used, and tissues from seropositive animals (cut-off $\geq 1: 64$ ) were submitted to Polymerase Chain Reaction (PCR) and immunohistochemistry (IHC). To assess the concordance between the direct techniques, the kappa test was used. In the IFAT, it was observed that $14 \%(14 / 100)$ of the ovine samples were serum-positive. In the PCR, $21.43 \%(3 / 14)$ of the animals were positive and in IHC, it was observed that $7.14 \%(1 / 14)$ were positively stained for T. gondii in cerebral tissue. Histopathologically, the predominant finding was the presence of mononuclear cell infiltrate in the heart and a perivascular cuff in the cerebrum and cerebellum. The concordance between the direct diagnosis techniques was moderate $(\mathrm{k}=0.44)$. Thus, it is important to use different direct techniques in diagnosing toxoplasmosis in naturally infected sheep.
\end{abstract}

Keywords: Sheep, Toxoplasma gondii, Polymerase Chain Reaction, histopathology, immunohistochemistry.

\section{Resumo}

O objetivo deste estudo foi pesquisar a ocorrência de Toxoplasma gondii em ovinos abatidos no Estado de Alagoas, Brasil por meio de diferentes técnicas de diagnóstico. Foram utilizadas amostras de soros e tecidos de 100 ovinos abatidos. Para a pesquisa de anticorpos foi utilizada a Reação de Imunofluorescência Indireta (RIFI), e os tecidos dos animais soropositivos (ponto de corte $\geq 1: 64$ ) foram submetidos às técnicas de Reação de Cadeia da Polimerase (PCR) e Imunohistoquímica (IHQ). Para o estudo da concordância entre as técnicas diretas foi empregado o teste Kappa. Na RIFI, $14 \%(14 / 100)$ das amostras foram soro-positivas. Na PCR, 21,43\% (3/14) dos animais foram positivos e, na IHC, 7,14\% (1/14) apresentaram marcação positiva para T. gondii no tecido cerebral. Na histopatologia, o achado predominante foi o infiltrado celular mononuclear no coração e manguito perivascular no cérebro e cerebelo. A concordância entre as técnicas diretas de diagnóstico foi moderada $(K=0,44)$. Desse modo, é importante utilizar diferentes técnicas diretas no diagnóstico da toxoplasmose em ovinos naturalmente infectados.

Palavras-chave: Ovino, Toxoplasma gondii, Reação em Cadeia da Polimerase, histopatologia, imunohistoquímica.

*Corresponding author: Rinaldo Aparecido Mota. Departamento de Medicina Veterinária, Universidade Federal Rural de Pernambuco - UFRPE, Rua Dom Manoel de Medeiros, s/n, Dois Irmãos, CEP 52171-900, Recife, PE, Brasil.

e-mail: rinaldo.mota@hotmail.com 


\section{Introduction}

Economic losses caused by Toxoplasma gondii infection in sheep are difficult to evaluate because this disease occurs sporadically (DUBEY, 2009). Animals such as sheep and goats kept on pastures have an increased risk of $T$. gondii infection due to the environmental contamination with oocysts this parasite (TENTER et al., 2000).

Toxoplasmosis in sheep can cause abortions, neonatal mortality, mummified fetuses or weak lambs at birth (DUBEY \& JONES, 2008; OIE, 2008). In the chronic form of the disease, most cases are not diagnosed or are confused with other similar diseases (BRAGA FILHO et al., 2010).

The diagnosis of toxoplasmosis can be made by means of indirect methods such as serological evaluation to detect specific antibodies. There are direct techniques to identificate tachyzoites and cysts in animal tissues by means of: histological sections stained with hematoxylin and eosin (HE), immunohistochemistry (IHC) techniques and bioassays in mice (ROSA et al., 2001). In histological sections stained with HE, it is difficult to identify cysts of $T$. gondii because the parasite can be confused with nuclei or nuclear fragments that stain similarly (TSUNEMATSU et al., 1964; BARBOSA, 1988). This technique is generally used to look for histological lesions consistent with infection by this parasite, with or without associated use of immunohistochemistry (UGGLA et al., 1987).

Different Polymerase Chain Reaction (PCR) techniques are also used to detect the fetal DNA of the parasite in tissues and fluids from aborted fetuses (OWEN et al., 1998; HURTADO et al., 2001).

There is no much information about the most appropriate direct technique to evaluate the presence of $T$. gondii in tissues from sheep naturally infected after a prior serological screening. The aim of this study was to investigate the occurrence of Toxoplasma gondii in sheep slaughtered, by means of different diagnosis techniques.

\section{Materials and Methods}

\section{Samples}

The present study was developed according to Brazilian laws and was approved by the Animal Use Ethics Committee (protocol number 59/2013).

One hundred blood samples ( 50 males and 50 females) were collected during bleeding of the sheep and tissues samples (cerebrum, cerebellum, pons, spinal cord and heart) were collected along of the slaughter line of the abattoir located in state of Alagoas, northeastern Brazil.

The sera samples were collected in microtubes and stored at $-20{ }^{\circ} \mathrm{C}$ until used. The tissue samples $(20 \mathrm{~g})$ were stored at $-80^{\circ} \mathrm{C}$ and tissue fragments $(0.5 \times 2 \times 2 \mathrm{~cm})$ in $10 \%$ buffered formalin.

\section{Experimental layout}

The steps of the present study are summarized below (Figure 1).

\section{Detection of antibodies}

The indirect immunofluorescence antibody test (IFAT) was performed to detect IgG antibodies against tachyzoites of T. gondii, in accordance with the method proposed by Camargo (1974), with a serum dilution of 1:64 (cut-off). In cases with a positive reaction, serum serial dilutions at two-fold increments were tested up to the endpoint titer. Ten microliters of sera were diluted in Phosphate Buffered Solution (PBS), pH 7.2, at room temperature and were placed in wells on T. gondii slides containing $\mathrm{RH}$ tachyzoites as the antigen, and incubated. The slides were washed in PBS ( $\mathrm{pH}=7.2)$, three times during ten minutes, followed by an incubation with rabbit antibody anti-sheep IgG conjugated for fluorescein isothiocyanate (Sigma Chemical, USA), diluted 1/250 in PBS containing 0.001\% of Evans Blue (Sigma Chemical, USA). The slides were washed again, covered with buffered glycerin ( $\mathrm{pH}$ 8.0) and a cover slip and then examined under a fluorescent microscope (Nikon Eclipse; objective: 40x) by one trained person. Positive and negative control was included in all the slides. For positive serum samples, diffuse or continuous peripheral membrane fluorescence was considered to be positive, but apical fluorescence alone was not. Serum samples that were positive with titers $\geq 1: 64$ were considered to be positive. Tissues from seropositive animals were submitted to PCR, histopathology and IHC.

\section{DNA extraction and Polymerase Chain Reaction}

DNA was extracted from tissues (cerebrum, cerebellum, pons, spinal cord and heart) using the commercial kit Wizard Genomic DNA Purification (Promega ${ }^{\circledR}$, USA), in accordance with the manufacturer's instructions.

Samples for the polymerase chain reaction (PCR) were prepared for a final volume of $12.5 \mu \mathrm{L}$ containing: $6.25 \mu \mathrm{L}$ of Top Taq Master Mix (Qiagen; Germany), $0.5 \mu \mathrm{L}$ of each primer $(10 \mu \mathrm{M}), 2.75 \mu \mathrm{L}$ of $\mathrm{ddH}_{2} \mathrm{O}$ and $2.5 \mu \mathrm{L}$ of DNA. The positive control for $T$. gondii was obtained from a suspension of intraperitoneal lavage material from mice previously infected with the $\mathrm{RH}$ strain. For the negative control, $2.5 \mu \mathrm{L}$ of $\mathrm{ddH}_{2} \mathrm{O}$ was added, replacing the DNA. The primers used were TOX 4 (5'-CGCTGCAGG-GAGGAAGACGAAAGTTG-3') and TOX5 (5'-CGCTGCAGACACAGTGCATCTGGATT-3'), thus obtaining a 529 bp fragment that is repeated 200- to 300 -fold in the genome of T.gondii.

PCR was performed as described by Homan et al (2000) with some modifications: an initial cycle of $94^{\circ} \mathrm{C}$ for $7 \mathrm{~min}$ (initial denaturation), followed by 35 cycles of $94^{\circ} \mathrm{C}$ for $1 \mathrm{~min}$ (denaturation), $60{ }^{\circ} \mathrm{C}$ for $1 \mathrm{~min}$ (annealing) and $72^{\circ} \mathrm{C}$ for $1 \mathrm{~min}$ (extension), followed by a final extension of $72^{\circ} \mathrm{C}$ for $10 \mathrm{~min}$. The PCR amplification was performed using an XP thermal cycler (Bioer Technology Co. Ltd., China).

The PCR product was subjected to electrophoresis. It was loaded into wells containing $2 \%$ agarose gel stained with blue-green dye I (LGC Biotecnologia, Brazil). The bands were viewed under ultraviolet light in a documentation system (L.PIX model, Loccus Biotecnologia $\left.{ }^{\circledR}\right)$. 


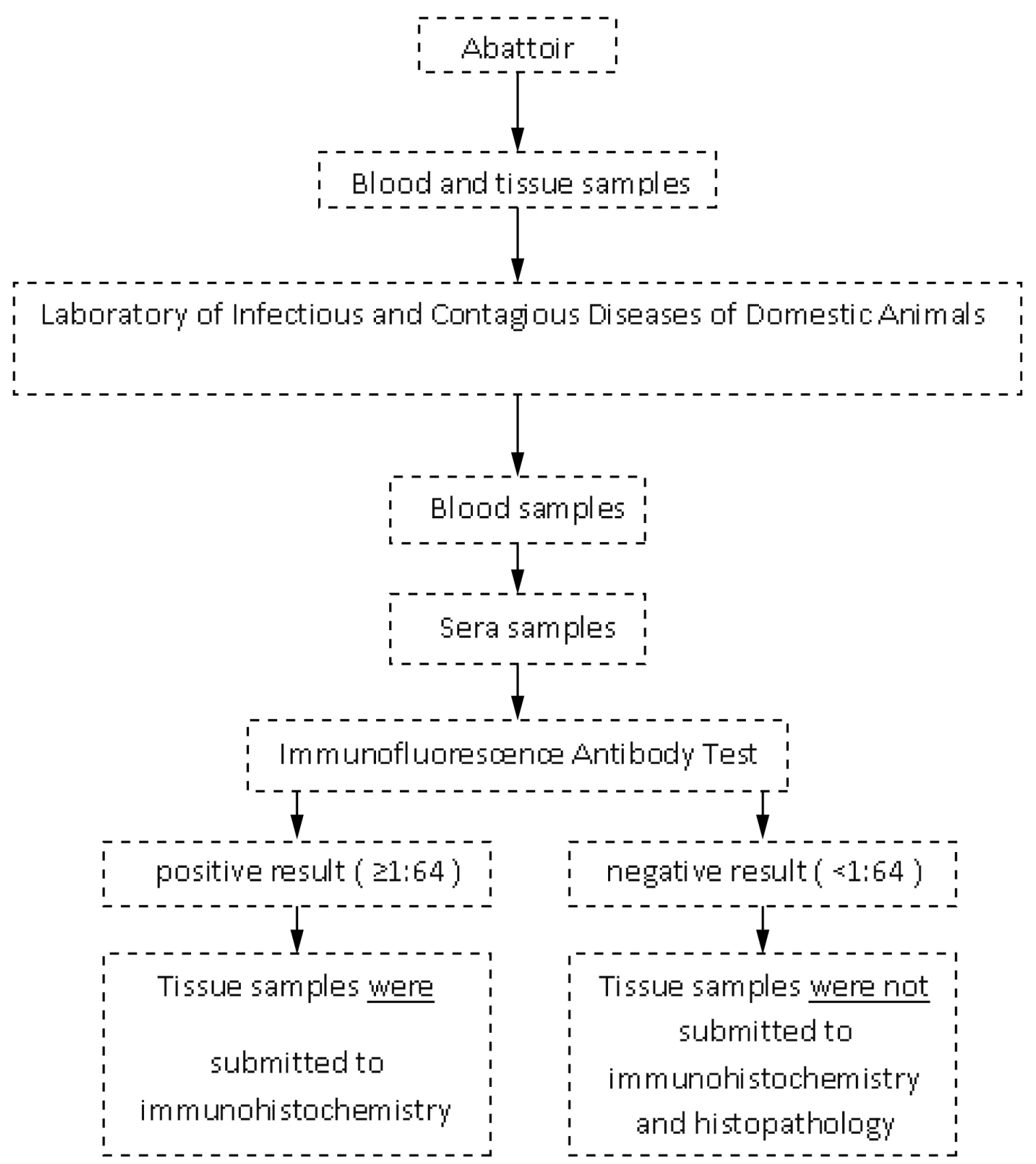

Figure 1. Sequence of procedures applied to diagnosis of Toxoplasma gondii in sera and tissue samples from sheeps naturally infected and slaughtered for human consumption in Alagoas, northeastern Brazil.

\section{Immunohistochemistry}

The immunohistochemistry technique was performed as described by Galiza et al. (2014), with some modifications: we used the labeled streptavidin biotin (LSAB) alkaline phosphatase technique (Dako Corporation, USA). The histological sections with $4 \mu \mathrm{m}$ fixed on silanized slides were dewaxed and hydrated. Inactivation of endogenous peroxidase was performed using 3\% hydrogen peroxide solution in distilled water at room temperature for 30 minutes and washed in PBS (0.01 M; $\mathrm{pH} 7.4)$. For antigen retrieval, the sections were subjected to heating in a water bath with citrate buffer ( $\mathrm{pH} 6.0 ; 10 \mathrm{mM})$ and were then placed in a microwave oven for 20 minutes at high power and washed twice in PBS afterwards. Non-specific binding was blocked by means of incubation with 5\% skim milk in PBS for 30 minutes at room temperature. After the slides had been washed with distilled water, they were immersed in PBS and then incubated with primary T. gondii antibody (Goat polyclonal antiserum \#210-70, VMRD, USA) diluted 1:200 in PBS ( $\mathrm{pH} 7.4$ ), in a moist chamber at $4{ }^{\circ} \mathrm{C}$ for overnight. After this period, the slides were washed in PBS and the commercial LSAB alkaline phosphatase (Dako Corporation, USA) kit was used. Subsequently, the sections were washed in PBS and the 
Permanent Red (Dako Corporation, USA) (chromogen) was used in accordance with the manufacturer's recommendations. Finally, the samples were counterstained with Harris hematoxylin (Sigma Chemical, USA), dehydrated, cleared in xylene (Vetec ${ }^{\circledR}$, Brasil) and mounted using balsam (Labsynth, Brasil), under a cover slip.

\section{Histopathology}

Different histological sections of the cerebrum, cerebellum, spinal cord and pons were cut and dehydrated in alcohols with increasing concentrations (from $70 \%$ to $100 \%$ ). These were then embedded in paraffin using routine processing. From each block, sections of $4 \mu \mathrm{m}$ thickness were cut, deparaffinized, rehydrated and stained with hematoxylin-eosin. All the slide was analyzed for presence of tissue cysts or histopathological lesions (Olympux BX40, objective 40x).

\section{Statistical analysis}

The Cohen's kappa coefficient (kappa) was used to assess the agreement between the techniques used. The kappa values were interpreted as described by Landis \& Koch (1977): $0.00-0.20$ = weak agreement; $0.21-0.40$ = regular agreement; $0.41-0.60$ = moderate agreement; $0.61-0.80$ = good agreement; $0.81-1.00=$ very good agreement. Negative values were interpreted as equal to 0.00 .

\section{Results}

The overall seroprevalence of $T$. gondii to IgG antibodies was $14 \%$ (14/100). Six males and eight females were seropositive with the following titers: 64 (6/14), 128 (1/14), 256 (4/14) and 1024 (3/14). Among the IFAT-positive sheep, three males were PCR-positive for T. gondii. Parasite DNA was detected in the spinal cord, cerebellum, cerebrum and heart. Among the IFAT-positive samples, the histopathological predominant findings were mononuclear cell infiltration in heart (Table 1) and a perivascular cuff in cerebrum and cerebellum (Figure 2). Only one sample of cerebellar tissue showed positive IHC staining. There was a moderate agreement between PCR and IHC results $($ kappa $=0.44)$.

\section{Discussion}

The seroprevalence results from the present study are in accordance with other results previously described in Brazil (PEREIRA et al., 2012; ANDRADE et al., 2013).

By means of IHC, T. gondii was found in central nervous system from asymptomatic sheep confirming the findings previously described by Esteban-Redondo et al. (1999), Motta et al. (2008) and Benavides et al. (2011). Weissmann (2003) recorded that the brain was considered the best tissue for sampling for immunohistochemical evaluation and confirmation of the diagnosis of toxoplasmosis. In the case of tissues from animals that were slaughtered or necropsied, it is useful to examine more
Table 1. Histopathological findings of tissues from sheep seropositive for Toxoplasma gondii.

\begin{tabular}{lc}
\hline \multicolumn{1}{c}{ Sample } & $\begin{array}{c}\text { Number of positive samples/total } \\
\text { number of animals }\end{array}$ \\
\hline $\begin{array}{l}\text { Heart } \\
\text { Mononuclear infiltration } \\
\text { between the myocytes }\end{array}$ & $8 / 14(57.14 \%)$ \\
$\begin{array}{l}\text { Cerebellum } \\
\text { Perivascular cuff }\end{array}$ & \\
$\quad$ Cyst & $2 / 14(14.28 \%)$ \\
Cerebrum & $1 / 14(7.14 \%)$ \\
$\quad$ Focal congestion & \\
$\quad$ Perivascular cuff & $1 / 14(7.14 \%)$ \\
\hline
\end{tabular}

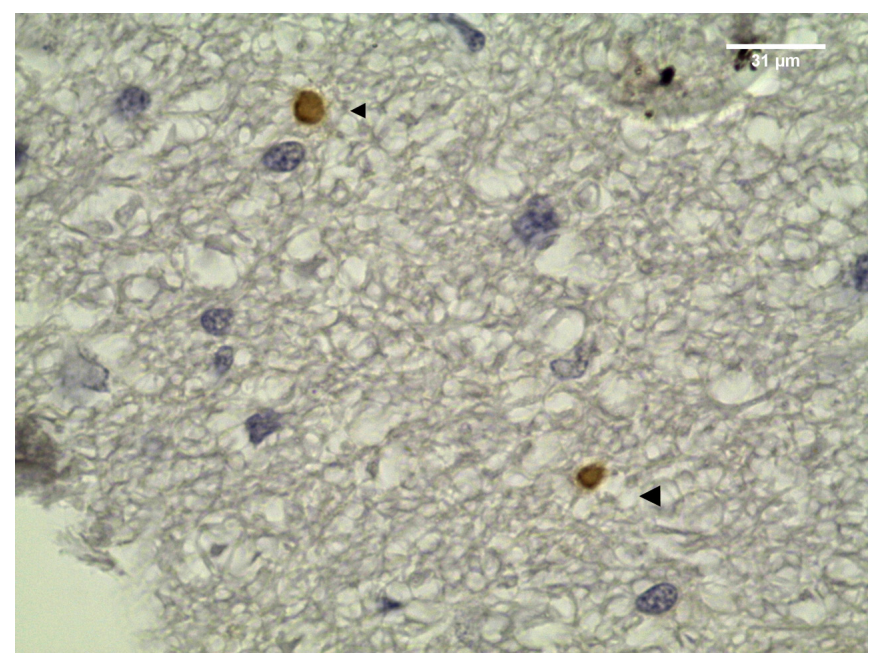

Figure 2. Toxoplasma gondii cysts in cerebellum section from IFAT-seropositive sheep for T.gondii IgG antibodies. Arrows: tissue cysts DAB-stained (objective 100x).

than one tissue type, such as the brain, heart or other tissue in which the parasite is frequently encysted. In this study, T. gondii also was detected in heart of sheep, in accordance with other studies that suggest that this organ may be the most appropriate tissue for detecting $T$. gondii infection using IHC (SILVA, 2011; VILLENA et al., 2012). Rosa et al. (2001) stated that during the asymptomatic phase of infection in experimentally infected goats, the cerebrum and the spinal cord are the most suitable tissues for isolating T. gondii. In the present study (which examined cases of natural infection), the PCR and IHC techniques respectively detected parasite DNA and T. gondii cysts, in the cerebrum, cerebellum and spinal cord. It is not possible to compare results relating to natural and experimental infections, given that in cases of natural infection, the infection phase and the strain might not be determined and the number of cysts is lower.

Although the histological findings in the present study were nonspecific, such findings have been widely described in cases of $T$. gondii infection (MCGAVIN \& ZACHARY, 2007). These histological alterations may differ between studies, especially with regard to the intensity of the mononuclear infiltrate observed in tissues targeted by the parasite. Silva (2011) reported congestion, followed by presence of inflammatory mononuclear cells or mild 
focal polymorphonuclear infiltrate. The complementary examination of the cerebrum may be useful, given that primary and secondary lesions by $T$. gondii may be found there. Gliosis around a central necrosis, sometimes mineralized with mild lymphocytic meningitis, represents a response to direct tissue damage caused by the parasite (MCGAVIN \& ZACHARY, 2007).

In one case of presence of a cyst in the cerebellum of a male sheep, as confirmed by means of IHC and PCR, there was no inflammatory reaction in the vicinity. Dubey et al. (1998) reported that intact tissue cysts probably do not cause any damage to the tissue and can persist without causing any inflammatory response by the host. According to Weiss \& Kim (2000), rupturing of tissue cysts induces a strong inflammatory response that results in formation of glial nodules in the cerebrum of chronically infected hosts.

Histopathological findings combined with IHC and clinical history allows for a definitive diagnosis of toxoplasmosis in most of cases (DAGLEISH et al., 2010).

Tachyzoites or cysts are difficult to identify in histological sections, especially when present in low numbers. Immunohistochemistry may facilitate the viewing of parasites in tissues (MCGAVIN \& ZACHARY, 2007; WAREE et al., 2007), but in cases of natural infection, this technique may have low sensitivity, as observed in the present study, in which most of the samples that were positive in serological and PCR evaluations were negative in IHC. The sensitivity of IHC is affected by the parasite inoculation routes, the infective form used, the species of the host, the strain virulence and the random distribution of the parasite in different tissues of the host. Thus, it is important to include samples from different tissues in order to increase the sensitivity of the technique.

Using IHC, positive staining for T. gondii was observed in the brain tissue of $7.14 \%(1 / 14)$ of the seropositive sheep. This differed from result obtained by Silva (2011), among naturally infected sheep, who reported that the positive staining rate was 52\% (12/25), using IHC. Among sheep in Rio de Janeiro, Brazil, Silva et al. (2013) concluded that IHC was proven to be effective in making the definitive diagnosis of toxoplasmosis. This was not confirmed in the present study, because the agreement between the PCR and IHC results was moderate $(\mathrm{k}=0.44)$. We therefore consider that the results were insufficient for this technique to be adopted in routine diagnostic laboratories. We recognize that there is some difficulty in identifying the infective forms of T. gondii in naturally infected animal tissues and that it is therefore more appropriate to use an association of direct diagnostic techniques in order to increase the chances of identifying the parasite.

The size of the sample examined has been described as one of the main limitations for detecting $T$. gondii infection in sheep tissue (ESTEBAN-REDONDO \& INNES, 1998). It is possible that the parasite is present in unanalyzed parts of tissues and, consequently, a negative result in the sample does not necessarily mean that the tissue is negative.

Esteban-Redondo \& Innes (1998) used PCR to detect the DNA of T. gondii in sheep inoculated with oocysts and observed positivity in $8 / 10$ samples, especially among the sheep that received high infective doses. According to Dubey (2010), the PCR technique is able to detect only one parasite, thus providing a quick and efficient diagnosis, but the positive result depends on the protozoa in the sample.

\section{Conclusion}

This study identified the presence of $T$. gondii cysts in tissues from seropositive sheep that had been slaughtered in Alagoas state, northeastern Brazil. The use of different direct techniques in association enhanced the chances of finding the parasite in tissue samples.

\section{References}

Andrade MMC, Carneiro M, Medeiros AD, Andrade Neto V, Vitor RW. Seroprevalence and risk factors associated with ovine toxoplasmosis in northeast Brazil. Parasite 2013; 20: 20. http://dx.doi.org/10.1051/ parasite/2013019. PMid:23707895.

Barbosa AJA. As técnicas de imunoperoxidase no estudo da etiologia das doenças infectuosas e parasitárias. Rev Soc Bras Med Trop 1988; 21(1): 1-6. http://dx.doi.org/10.1590/S0037-86821988000100001. PMid:3068711.

Benavides J, Maley S, Pang Y, Palarea J, Eaton S, Katzer F, et al. Development of lesions and tissue distribution of parasite in lambs orally infected with sporulated oocysts of Toxoplasma gondii. Vet Parasitol 2011; 179(1-3): 209215. http://dx.doi.org/10.1016/j.vetpar.2011.03.001. PMid:21440372.

Braga-Filho E, Ramos OS, Freitas JA. Inquérito sorológico de Toxoplasma gondii em ovinos na microrregiāo Castanhal, Pará, Brasil. Arq Inst Biol 2010; 77(4): 707-710.

Camargo ME. Introdução às técnicas de imunofluorescência. Rev Bras Patol Clin 1974; 10: 143-169.

Dagleish MP, Benavides J, Chianini F. Immunohistochemical diagnosis of infectious diseases of sheep. Small Rumin Res 2010; 92(1-3): 19-35. http://dx.doi.org/10.1016/j.smallrumres.2010.04.003.

Dubey JP, Jones JL. Toxoplasma gondii infection in humans and animals in the United States. Int J Parasitol 2008; 38(11): 1257-1278. http:// dx.doi.org/10.1016/j.ijpara.2008.03.007. PMid:18508057.

Dubey JP, Lindsay DS, Speer CA. Structures of Toxoplasma gondii tachyzoites, bradyzoites, and sporozoites and biology and development of tissue cysts. Clin Microbiol Rev 1998; 11(2): 267-299. PMid:9564564.

Dubey JP. Toxoplasmosis in pigs: the last 20 years. Vet Parasitol 2009; 164(2-4): 89-103. http://dx.doi.org/10.1016/j.vetpar.2009.05.018. PMid:19559531.

Dubey JP. Toxoplasmosis of animals and humans. Boca Raton: CRC Press; 2010.

Esteban-Redondo I, Innes EA. Detection of Toxoplasma gondii in tissues of sheep orally challenged with different doses of oocysts. Int J Parasitol 1998; 28(9): 1459-1466. http://dx.doi.org/10.1016/S0020-7519(98)00116-7. PMid:9770633.

Esteban-Redondo I, Maley SW, Thomson K, Nicoll S, Wright S, Buxton $\mathrm{D}$, et al. Detection of T. gondii in tissues of sheep and cattle following oral infection. Vet Parasitol 1999; 86(3): 155-171. http://dx.doi.org/10.1016/ S0304-4017(99)00138-7. PMid:10511098.

Galiza GJN, Tochetto C, Rosa FB, Panziera W, Silva TM, Caprioli RA, et al. Usage of three immunohistochemical methods in the detection of aspergillosis and zygomycosis in animals. Pesqui Vet Bras 2014; 34(7): 637-642. http://dx.doi.org/10.1590/S0100-736X2014000700005.

Homan WL, Vercammen M, De Braekeleer J, Verschueren H. Identification of a 200 - to 300-fold repetitive 529 bp DNA fragment in Toxoplasma 
gondii, and its use for diagnostic and quantitative PCR. Int J Parasitol 2000; 30(1): 69-75. http://dx.doi.org/10.1016/S0020-7519(99)001708. PMid:10675747.

Hurtado A, Aduriz G, Moreno B, Barandika J, García-Pérez AL. Single tube nested PCR for the detection of Toxoplasma gondii in fetal tissues from naturally aborted ewes. Vet Parasitol 2001; 102(1-2): 17-27. http:// dx.doi.org/10.1016/S0304-4017(01)00526-X. PMid:11705648.

Landis JR, Koch GG. The measurement of observer agreement for categorical data. Biometrics 1977; 33(1): 159-174. http://dx.doi. org/10.2307/2529310. PMid:843571.

McGavin MD, Zachary JF. Pathologic basis of veterinary disease. Missouri: Mosby; 2007.

Motta AC, Vieira MIB, Bondan C, Edelweiss MIA, Dametto MA, Gomes A. Aborto em ovinos associada à toxoplasmose: Caracterização sorológica, anátomo-patológica e imunoistoquímica. Rev Bras Parasitol Vet 2008;17(Suppl 1): 204-208. PMid:20059849.

Organisation Mondiale de la Santé Animale - OIE. Toxoplasmosis. In: Organisation Mondiale de la Santé Animale - OIE. OIE Terrestrial Manual. Paris; 2008 [cited 2015 Jan 13]. Available from: http://www.oie. int/fileadmin/Home/eng/Health_standards/tahm/2.09.10_TOXO.pdf

Owen MR, Clarkson MJ, Trees AJ. Diagnosis of toxoplasma abortion in ewes by polymerase chain reaction. Vet Rec 1998; 142(17): 445-448. http://dx.doi.org/10.1136/vr.142.17.445. PMid:9602512.

Pereira MF, Peixoto RM, Langoni H, Greca H Jr, Azevedo SS, Porto WJN, et al. Fatores de risco associados à infecção por Toxoplasma gondii em ovinos e caprinos no estado de Pernambuco. Pesqui Vet Bras 2012; 32(2): 140-146. http://dx.doi.org/10.1590/S0100-736X2012000200009.

Rosa C, Kasai N, Souza SLP, Guerra JL, Rego AA, Gennari SM. Comparação das técnicas de imuno-histoquímica e bioensaio em camundongos para pesquisa de Toxoplasma gondii em tecidos de caprinos, experimentalmente inoculados. Arq Inst Biol 2001; 68(1): 13-17.
Silva AF, Oliveira FC, Leite JS, Mello MF, Brandão FZ, Leite RI, et al. Immunohistochemical identification of Toxoplasma gondii in tissues from Modified Agglutination Test positive sheep. Vet Parasitol 2013; 191(3-4): 347-352. http://dx.doi.org/10.1016/j.vetpar.2012.09.022. PMid:23062690.

Silva AF. Anátomo-histopatologia, imuno-histoquimica e análises clinicas de ovinos infectados naturalmente por Toxoplasma gondii e Neospora caninum no estado do Rio de Janeiro [Master Dissertation]. Rio de Janeiro: Universidade Federal Fluminense; 2011.

Tenter AM, Heckeroth AR, Weiss LM. Toxoplasma gondii: from animals to humans. Int J Parasitol 2000; 30(12-13): 1217-1258. http://dx.doi. org/10.1016/S0020-7519(00)00124-7. PMid:11113252.

Tsunematsu Y, Shioiri K, Kusano N. Three cases of lymphadenopathy toxoplasmic with special reference to the application of fluorescent antibody technique for detection of Toxoplasma in tissue. Jpn J Exp Med 1964; 34: 216-230. PMid:14233272.

Uggla A, Sjöland L, Dubey JP. Immunohistochemical diagnosis of toxoplasmosis in fetuses and fetal membranes of sheep. Am J Vet Res 1987; 48(3): 348-351. PMid:3551698.

Villena I, Durand B, Aubert D, Blaga R, Geers R, Thomas M, et al. New strategy for the survey of Toxoplasma gondii in meat for human consumption. Vet Parasitol 2012; 183(3-4): 203-208. http://dx.doi. org/10.1016/j.vetpar.2011.08.001. PMid:21864981.

Waree P, Ferguson DJ, Pongponratn E, Chaisri U, Sukthana Y. Immunohistochemical study of acute and chronic toxoplasmosis in experimentally infected mice. Southeast Asian J Trop Med Public Health 2007; 38(2): 223-231. PMid:17539270.

Weiss LM, Kim K. The development and biology of bradyzoites of Toxoplasma gondii. Front Biosci 2000; 5(1): 391-405. http://dx.doi. org/10.2741/Weiss. PMid:10762601.

Weissmann J. Presumptive Toxoplasma gondii abortion in a sheep. Can Vet J 2003; 44(4): 322-324. PMid:12715986. 